\title{
The Influence Of Strategic Agility On The Perceived Performance Of Manufacturing Firms In Nigeria
}

Onyema .E. Ofoegbu, Ajayi Crowther University, Nigeria

Paul Ayobami Akanbi, Ajayi Crowther University, Nigeria

\begin{abstract}
Strategic agility is learning to make fast turns and being able to transform and renew the organization without losing momentum. Strategic agility can bring about organizations that can produce the right products and services at the right place at the right time at the right price and for the right customers. Manufacturing firms and indeed all organizations that are strategically agile can contribute immensely to the achievement of the millennium development goals by contributing to economic growth. This paper examined the impact of strategic agility on the perceived performance of some selected manufacturing firms in Awe, Oyo, Oyo State Nigeria. The study employed survey research using questionnaire to collect data from all categories of workers in the two selected manufacturing firms. Two hundred and ten subjects responded to the questionnaire. Five hypotheses were tested using multiple regression, $t$-test, correlation analysis and analysis of variance. The study indicated that strategic agility as measured by strategic sensitivity, collective commitment or leadership unity and resource fluidity can have a significant impact on the performance of manufacturing firms. Based on the findings, it was recommended that firms should be proactive rather than reactive in order to promptly and effectively deal with changes taking place in the complex business environment and also improve their performance.
\end{abstract}

Keywords: Strategic Agility; Strategic Sensitivity; Collective Commitment; Resource Fluidity; Perceived Organizational Performance

\subsection{INTRODUCTION}

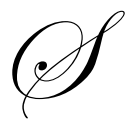

trategic agility is learning to make fast turns and being able to transform and renew the organization without losing momentum. Strategic agility can bring about organizations that can produce the right products and services at the right place at the right time at the right price and for the right customers. Manufacturing firms and indeed all organizations that are strategically agile can contribute immensely to the achievement of the millennium development goals by contributing to economic growth.

Strategic agility is the ability to continuously and adequately adjust and adapt in appropriate time the strategic direction in core business in relation to changing circumstances, be known by sensitivity to the environment. This may include creating new products and services or creating new business models and innovative ways to create value for the company. (Swafford et al., 2006). The performance of a company depends on its activities and activities of its competitors, customers, suppliers, partners and governments. These activities could wholly be referred to as the business environment (Turban et al, 2008). The current business environment characterized by intense technological innovation, powerful customers with diverse requirements and short product life cycle in a global economy have significantly shortened market visibility and increased uncertainty (Swafford et al., 2006).

Organizations must respond to the challenges and opportunities brought by the business pressures in order to survive or gain sustainable competitive advantages. This hyper-competitive environment requires specific 
dynamic strategies to gain competitive advantage and sometimes even to survive (Wiggins \& Ruefli, 2005). For instance, competition has become so intense that companies have been forced to collaborate and formulate survival strategies. Customer focus, electronic commerce, intelligent data management and business networks are some of the noticeable business responses (Turban et al, 2008). It is against this background that this study on the influence of strategic agility on the perceived performance of manufacturing firms in Nigeria is conceived.

\subsection{Objectives and Hypotheses}

The objectives of this study are five which are embedded in the hypotheses stated below:

- $\quad$ Strategic sensitivity, Collective commitment, and Resource fluidity will jointly and independently predict Perceived organizational performance.

- $\quad$ There will be a significant difference between strategic sensitivity and perceived organizational performance.

- There will be a significant relationship between Perceived Organizational performance and Collective commitment.

- There will be main and interaction effect of Strategic sensitivity and Collective commitment on perceived organizational performance.

- $\quad$ There will be a significant relationship between resource fluidity perceived organizational performance.

\subsection{LITERATURE REVIEW AND CONCEPTUAL FRAMEWORK}

There is no life without uncertainty and uncertainty is a key characteristic of any economic activity. Planning is extremely difficult in an uncertain environment hence businesses should attempt to mitigate the impact of uncertainty by proactively anticipating change and getting equipped to manage change (Oetinger, 2004). Companies in today's world face great environmental turbulence due to ever-evolving competition, changing technology, fluctuating demand, disruption in the supply chain caused by man made or natural disasters, etc. High levels of environmental turbulence can paralyze a firm's operations. Turbulence is comprised of uncertainty and risks faced by a firm. Consequently, managing uncertainty and reducing risk should be the focus of firms.

Building strategic agility in firms is a way to manage unforeseen changes and risks faced by firms. Agility has been defined as the capability of surviving and prospering in the competitive environment of continuous and unpredictable change by reacting quickly and effectively to changing markets, driven by custom designed products and service (Gunasekeran, 1999). Strategically agile firms utilize strategies aimed at being responsive and flexible to customer needs, while the risks of supply shortages or disruptions are hedged by pooling inventory or other capacity resources. Firms that have the capability to be responsive to the changing, diverse and unpredictable demands of customers on the front end, while minimizing the back end risks to supply disruptions (Lee, 2002) can be seen as strategically agile. If a company disregards the importance of agility, the consequences can be disastrous.

Strategic sensitivity is a combination of foresight, insight and simple probing, with the most importance on insight (Doz \& Kosonen, 2008). Strategic sensitivity means being open to as much information, intelligence and innovations as possible by creating and maintaining relationships with a variety of different people and organizations (Doz \& Kosonen, 2008). Sull (2009) defines the same phenomenon as consistently identifying and seizing opportunities more quickly than the competitors. According to him, companies need to have shared real time market data that is detailed and reliable; small number of corporate priorities in order to focus efforts; clear performance goals for teams and individuals; and mechanisms to hold people accountable and to reward them (Sull, 2009). What it takes from the management is following the flow of information, sustaining a sense of urgency, maintaining focus on critical objectives, and recruiting entrepreneurial employees (Sull, 2009).

One aspect of collective commitment is organising for mutual dependency along the value chain or functions, for example by giving individual executives responsibility for different stages in the company's value chain, instead of only giving them formal responsibility for a business unit. Common functions and value creation logic can be utilised as integrators. Common, horizontal functions serve all the vertical units and therefore they have a companywide understanding of the needs of different units. Common value creation logic on the other hand helps 
to maintain a shared approach between different units, which prevents being divided into separate silos. Also distributing corporate wide leadership roles beyond the unit responsibilities enhances collective commitment(Doz \& Kosonen, 2008). Learning to work together is not easy for executives that have their own units, but it is crucial when it comes to reaching collective commitment (Doz \& Kosonen, 2008). This can be helped by focusing on corporate issues instead of unit level issues, and creating a shared incentives plan as well as transparent goals and a fair process (Doz \& Kosonen, 2008). Overlapping areas of expertise within top management are a source of strength, and they should be utilized to relate and build on one another's points of view instead of just arguing (Doz \& Kosonen,2008). However, it is also important to embrace conflicts rather than avoid them, as well as to keep the dialogue direct and informal (Doz \& Kosonen, 2008).

Without resource fluidity strategic sensitivity and collective commitment remain useless (Doz \& Kosonen, 2008). Resource fluidity means being able to flexibly move resources from one place to another as needed (Doz \& Kosonen, 2008; Hamel, 2007; Sull, 2009). According to Sull (2009), what is needed to achieve this is a diversified portfolio of independent units, a cadre of general managers who can be transferred across units, central corporate control over key resources, and structured processes for decreasing investments or selling of units. The biggest challenge in doing this is that most of the resources are tied to some function, and it may be difficult to reallocate those resources, especially when it would be for something else than the traditional core business - this relates to over-funding of legacy businesses (Doz \& Kosonen, 2008). In order to overcome this challenge, the management needs to base their decisions on rational rather than emotional or political criteria, invest heavily in promising opportunities (Sull, 2009), and restrict over investment in the core business (Doz \& Kosonen, 2008). It is also important not to allocate resources into subunits in a way that cannot be changed without a major reorganisation, but rather provide multiple channels for accessing resources i.e. several places where managers can get access to resources when they need them instead of having just one person that acts as a gate (Doz \& Kosonen, 2008). Resource fluidity requires disciplined processes for evaluating individual units and reallocating key resources (Sull, 2009), i.e. having only one set of performance data (Doz \& Kosonen, 2008). This means that the same evaluation system is used across the organisation, and different units and functions can easily be compared to other units and functions in the same organisation (Doz \& Kosonen, 2008). It is also important to establish dynamic governance mechanisms in order to know where to allocate resources and reassign responsibilities in a fast and flexible manner, as well as set common rules for resource allocation (Doz \& Kosonen, 2008). Also an adjustable planning process is needed that questions the primacy of the core business and is rather based on real market events than the calendar (Doz \& Kosonen, 2008). Another challenge is protectionism for one's own resources - managers do not necessarily want to share them with one another (Doz \& Kosonen, 2008; Hamel, 2007). However, top management needs to have the courage to make even difficult and unpopular decisions when it is needed (Sull, 2009). One way of mitigating this risk is to dissociate business results from resource ownership, meaning that no single dimension or unit in the organisation owns the resources needed to conduct its business, but they are commonly shared (Doz \& Kosonen,2008). One way of doing this is by planning, creating and delivering work under purpose specific crosscompany programmes and projects, and in that way releasing the resources to companywide uses (Doz \& Kosonen, 2008).

\subsection{METHOD}

\subsection{Research Design}

This study employed the survey design method. The independent variable was strategic agility which was measured by strategic sensitivity, collective commitment/leadership unity, and resource fluidity and the dependent variable was perceived organizational performance.

\subsection{Sample}

The sample of this study comprised two hundred and ten employees of two manufacturing firms in Awe, Oyo State, Nigeria. The firms were Bond Chemicals and ARMO BYNG. The samples were randomly selected through stratified random sampling across different cadres and departments. A total of two hundred and thirty questionnaires were distributed, with a number of two hundred and ten found usable and were analysed. The subjects were made up of one hundred and three males and one hundred and seven females with age ranged between 18 and 56. 


\subsection{Instruments}

The instrument of the study was a questionnaire which was divided into three sections, namely A to C. Section A measured the demographic information, B measured strategic agility, and C measured perceived organizational performance. The strategic agility scale was a 15 item scale adapted from a scale developed by Ojha ( 2008) with a Likert scale scoring format ranging from strongly agree (5) to strongly disagree (1).The Cronbach's álpha value of the scale was 0.89 . Six items measured strategic sensitivity, six items measured collective commitment while the remaining three items measured resource fluidity. The organizational performance scale was adapted from a scale developed by Khandwalla (1977) and David Wan et. al (2002) which is an eighth item scale with a Likert scoring format ranging from very high (6) to very low (1). The scales were revalidated and the Cronbach alphas gave the following results: strategic sensitivity 0.99 ; collective commitment 0.99 ; resource fluidity 0.94; and perceived organizational performance 0.97 .

\subsection{Data analyses}

The demographic information was analysed using frequency counts and simple percentage. Hypothesis 1 was tested using multiple regression, hypothesis 2 was tested with t-test, hypotheses 3 and 5 were tested using Pearson Correlation and hypothesis 4 was tested with analysis of variance.

\subsection{DATA PRESENTATION AND ANALYSES}

Table 4.1: Descriptive Statistics of demographics

\begin{tabular}{|c|c|c|}
\hline Sex & Frequency & Percentage \\
\hline Male & 103 & 49.0 \\
\hline Female & 107 & 51.0 \\
\hline Total & 210 & 100.0 \\
\hline Age & Frequency & Percentage \\
\hline $18-25$ & 35 & 16.7 \\
\hline $26-35$ & 28 & 13.3 \\
\hline $36-45$ & 67 & 31.9 \\
\hline $46-55$ & 49 & 23.3 \\
\hline 56 and above & 31 & 14.8 \\
\hline Total & 210 & 100.0 \\
\hline Marital status & Frequency & Percentage \\
\hline Single & 45 & 21.4 \\
\hline Married & 118 & 56.2 \\
\hline Divorced & 36 & 17.1 \\
\hline Separated & 11 & 5.2 \\
\hline Total & 210 & 100.0 \\
\hline $\begin{array}{r}\text { Educational status } \\
\end{array}$ & Frequency & Percentage \\
\hline Post graduate & 33 & 15.7 \\
\hline B.sc, HND & 97 & 46.2 \\
\hline OND,NCE & 64 & 30.5 \\
\hline SSCE & 8 & 3.8 \\
\hline primary school & 8 & 3.8 \\
\hline Total & 210 & 100.0 \\
\hline Cadre & Frequency & Percentage \\
\hline Management staff & 104 & 49.5 \\
\hline Senior staff & 57 & 27.1 \\
\hline Junior staff & 49 & 23.3 \\
\hline Total & 210 & 100.0 \\
\hline
\end{tabular}

Field survey, 2011

The table above showed that $103(49.0 \%)$ of the respondents were male while their female counterparts were $107(51.0 \%), 35(16.7 \%)$ respondents were within the age space of $18-25$ years, $28(13.3 \%)$ were within the age 
space of 26-35 years, 67(31.9\%) were within the age space of 36-45 years, 49(23.3\%) were within 46-55 years of age while $31(14.8 \%)$ were 56 and above years respectively. The table also indicated that $45(21.4 \%)$ respondents were single, $118(56.2 \%)$ were married, $36(17.1 \%)$ were divorced while $11(5.2 \%)$ were Separated. The table also revealed that 33(15.7\%) respondents had Post graduate qualification, 97(46.2\%) had B.sc, HND certificate, 64(30.5\%) had OND,NCE certificate, $8(3.8 \%)$ had Secondary school leaving certificate while $8(3.8 \%)$ also had primary school leaving certificate. The table showed that majority 104(49.5\%) of the respondents were Management staff, 57(27.1\%) were Senior staff while 49(23.3\%) were Junior staff respectively.

\section{2: HYPOTHESES TESTING}

\section{Hypothesis 1}

Strategic sensitivity, collective commitment and resource fluidity will jointly and independently predict perceived organizational performance.

H1a: There will be a joint effect of independent variables (Strategic sensitivity, Collective commitment, and

Resource fluidity) on Perceived organizational performance.

Table 4.2.1a: summary table showing a joint effect of Strategic sensitivity, Collective commitment, and Resource fluidity on Perceived organizational performance

\begin{tabular}{|l|c|c|c|c|c|}
\hline \multicolumn{1}{|c|}{ Model } & Sum of Squares & DF & Mean Square & F & Sig. \\
\hline Regression & 944.624 & 3 & 314.875 & 50.437 & .000 \\
Residual & 1286.043 & 206 & 6.243 & & \\
Total & 2230.667 & 209 & & & \\
\hline
\end{tabular}

$\mathrm{R}=.651 \mathrm{R}^{2}=.42 \operatorname{Adj} \mathrm{R}^{2}=.415$

It was shown in the table above that the joint effect of independent variables (Strategic sensitivity, Collective commitment, and Resource fluidity) on Perceived organizational performance was significant $(\mathrm{F}(3,206)=$ $50.437 ; \mathrm{R}=.651, \mathrm{R}^{2}=.423$, Adj. $\mathrm{R}^{2}=0.415 ; \mathrm{P}<.05$ ). About $42 \%$ of the variation was accounted for by the independent variables. The hypothesis is therefore accepted.

H1b: There will be a relative effect of independent variables (Strategic sensitivity, Collective commitment, and Resource fluidity) on Perceived organizational performance.

Table 4.2.1b: showing the relative effect of independent variables(strategic sensitivity, collective commitment and resource fluidity) on perceived organizational performance

\begin{tabular}{|l|c|c|c|c|c|}
\hline \multirow{2}{*}{ Model } & \multicolumn{2}{|c|}{$\begin{array}{c}\text { Unstandardized } \\
\text { Coefficient }\end{array}$} & $\begin{array}{c}\text { Standardized } \\
\text { Coefficient }\end{array}$ & \multicolumn{1}{|c|}{ T } & \\
\cline { 2 - 5 } & B & Std. Error & B & & \\
\hline (Constant) & 26.215 & .681 & & 38.484 & .000 \\
Strategic sensitivity & -.368 & .053 & -.768 & -7.005 & .000 \\
Collective commitment & .506 & .177 & 1.097 & 2.864 & .005 \\
Resource fluidity & .105 & .353 & .107 & .298 & .766 \\
\hline
\end{tabular}

The result above showed the relative contribution of each of the independent variables on the dependent: Strategic sensitivity $(\beta=-.768, \mathrm{P}<.05)$, Collective commitment $(\beta=1.097, \mathrm{P}<.05)$, and Resource fluidity $(\beta=.107$, $\mathrm{P}>.05)$ respectively.

Hence, Strategic sensitivity and Collective commitment were found significant while Resource fluidity was not. Therefore, strategic sensitivity, collective commitment and resource fluidity jointly and independently predicted perceived organizational performance. 


\section{Hypothesis 2}

H2: There will be a significant difference between strategic sensitivity and perceived organizational performance.

Table 4.2.2: Summary table showing the significant difference between strategic sensitivity and perceived organizational performance

\begin{tabular}{|l|c|c|c|c|c|c|c|}
\hline \multicolumn{1}{|c|}{ Organizational performance } & $\mathbf{N}$ & Mean & Std. Dev. & Crit-t & Cal-t. & DF & P \\
\hline Low & 52 & 28.4231 & 1.3038 & \multirow{2}{*}{1.96} & \multirow{2}{*}{6.200} & 208 & .000 \\
High & 158 & 31.4051 & 3.3823 & & & & \\
\hline
\end{tabular}

The above table showed that there was a significant difference between strategic sensitivity and perceived organizational performance $($ Crit- $\mathrm{t}=1.96$, Cal.t $=6.200, \mathrm{df}=208, \mathrm{P}<.05$ level of significance). The hypothesis is therefore accepted.

\section{Hypothesis 3}

H3: There will be a significant relationship between collective commitment and perceived organizational performance.

Table 4.2.3: Summary table showing the significant relationship between collective commitment and perceived organizational performance

\begin{tabular}{|l|c|c|c|c|c|c|}
\hline \multicolumn{1}{|c|}{ Variable } & Mean & Std. Dev. & N & R & P & Remark \\
\hline Organizational performance & 30.6667 & 3.2670 & \multirow{2}{*}{210} & $.554 * *$ & .000 & Sig. \\
Collective commitment & 01.7381 & 0.4407 & & & & \\
\hline
\end{tabular}

** sig at .01 level

It is shown in the above table that there was a significant relationship between collective commitment and perceived organizational performance $\left(\mathrm{r}=.554^{*}, \mathrm{~N}=210, \mathrm{P}<.05\right)$. The hypothesis is therefore accepted.

\section{Hypothesis 4}

H4: There will be main and interaction effect of Strategic sensitivity and Collective commitment on Perceived Organizational performance.

Table 4.2.4: Summary table showing the main and interaction effect of Strategic sensitivity and Collective commitment on Perceived Organizational performance

\begin{tabular}{|l|c|c|c|c|c|}
\hline \multicolumn{1}{|c|}{ Source } & Sum of Squares & DF & Mean Square & F & Sig. \\
\hline Main Effect: & 877.193 & 3 & 292.398 & 44.503 & .000 \\
Strategic sensitivity Collective & 44.744 & 1 & 44.744 & 6.810 & .010 \\
commitment & 264.702 & 1 & 264.702 & 40.288 & .000 \\
2-way Interactions: & & & & \\
$\begin{array}{l}\text { Strategic sensitivity x Collective } \\
\text { commitment }\end{array}$ & 94.284 & 1 & 94.284 & 14.350 & .000 \\
Explained & 877.193 & 3 & 292.398 & \\
Residual & 1353.474 & 206 & 6.570 & \\
Total & 2230.667 & & & \\
\hline
\end{tabular}


In the table above, it was observed that there was significant difference in the Main effect of Strategic sensitivity and Collective commitment. The Interaction effect of Strategic sensitivity and Collective commitment on Perceived Organizational Performance however, was significant $(\mathrm{F}(3,206)=14.350, \mathrm{P}<.05)$.

The hypothesis is accepted, as there was significant difference in the interaction effect of strategic sensitivity and collective commitment on perceived Organizational performance.

\section{Hypothesis 5}

H5: There will be a significant relationship between resource fluidity perceived organizational performance.

Table 4.2.5: Summary table showing the significant relationship between Resource Fluidity and perceived organizational performance

\begin{tabular}{|l|c|c|c|c|c|c|}
\hline \multicolumn{1}{|c|}{ Variable } & Mean & Std. Dev. & N & R & P & Remark \\
\hline Organizational performance & 30.6667 & 3.2670 & 210 & $.535^{* *}$ & .000 & Sig. \\
Resource fluidity & 11.7190 & 3.3263 & & & \\
\hline ** sig at .01 level
\end{tabular}

** sig at .01 level

It is shown in the above table that there was significant relationship between Perceived Organizational performance and Resource fluidity $\left(\mathrm{r}=.535^{* *}, \mathrm{~N}=210, \mathrm{P}<.05\right)$. The hypothesis is accepted.

\section{CONCLUSION}

This study had examined the influence of strategic agility on the perceived performance of manufacturing firms in Nigeria. The results showed that strategic sensitivity, collective commitment and resource fluidity were positively related to perceived organizational performance. The hypotheses tested supported earlier study by Ojha (2008) who submitted that strategic agility has the capability to positively influence organizational performance and operations competitive capabilities and that strategic agility enhanced an organization's operations competitive capabilities. This study concludes that the independent variables used in measuring strategic agility were predictors of perceived organizational performance. There was also main and interaction effect of strategic sensitivity, collective commitment and resource fluidity on perceived organizational performance.

\section{RECOMMENDATIONS}

Based on the findings from this study, the following are recommended:

- $\quad$ Firms should be proactive rather than reactive in order to promptly and effectively deal with changes taking place in the complex business environment and also improve their performance.

- Organizations should carry along all employees in decision making and ensure that everybody in the organization has a sense of belonging to be motivated to contribute to overall organizational performance.

- $\quad$ Firms should ensure that their strategic agility is sustained to bring about sustained competitive advantage.

- $\quad$ There should be increased focus on implementation, not only on planning and decision making.

\section{AUTHOR INFORMATION}

Dr. Onyema Eugene Ofoegbu is a Nigerian. He has B.Sc degree in Nutrition science from Gordon's Institute of Technology Aderdeen Scotland in 1978, a M.Sc degree in Management and Technology from University of Wales in 1980 and a Ph. D degree in Management Sciences from University of Ilorin, Ilorin, Nigeria. He retired as a Director of Administration in Agricultural and Rural Management Training Institute ( ARMTI), Ilorin in 2006. He is currently lecturing at the department of Business Administration, Faculty of Social and Management Sciences, Ajayi Crowther University, P.M.B.1066,Oyo, Oyo State Nigeria. His areas of interest include Strategic Management and its application to organizations, Organization Behaviour and Corporate Governance. My email address and 
telephone are eugeneofoegbu@yahoo.com and +234-8056463069. Dr Ofoegbu is a fellow of the British Institute of Personnel and Development. Corresponding author.

Mr. Paul Ayobami Akanbi is a graduate of Business Administration from Olabisi Onabanjo University, AgoIwoye, Ogun State. He also holds a masters degree in Business Administration from the University of Ilorin, Kwara State. He is currently running his doctoral degree programme in Management Sciences at the Ladoke Akintola University, Ogbomoso, Nigeria. He is also a member of the Institute of Strategic Management of Nigeria (ISMN). His areas of interest are strategic/general management, entrepreneurship and marketing research. Mr. Akanbi lectures at the department of Business Administration, Ajayi Crowther University, P.M.B. 1066, Oyo, Oyo State, Nigeria. My e-mail address and telephone number are paulayobami@yahoo.com and +234-8034813651

\section{REFERENCES}

1. David, W., Chin, H. O and Victor, K. (2002). Strategic Human Resource Management and organizational Performance in Singapore. Sage Publications, July/August.

2. Doz,Y. \& Kosonen, M.(2008).FastStrategy. Wharton. School Publishing, Harlow.

3. Doz Y, Kosonen M (eds.) (2008), Fast Strategy: How strategic agility will help you stay ahead of the game, Pearson Education limited.

4. Doz Y, Kosonen M (2008), The Dynamics of Strategic Agility: Nokia's Rollercoaster Experience, California Management Review, Vol. 50, No. 3, pp. 95-118

5. Gunasekaran, A., 1999. Agile manufacturing: a framework for research and development. International Journal Production Economics. 62 (1-2), 87-105.

6. Hamel, G. (2007), The Future of Management, Harvard Business School Press, Boston.

7. Khandwalla, P.(1977).The design of organizations. New York: Harcourt Brace Jovanovich.

8. Lee, Hau L., 2002. Aligning Supply Chain Strategies with Product Uncertainties. California Management Review. 44 (3), 105-119.

9. Oetinger, Bolko Von, 2004. A plea for uncertainty: Everybody complains about uncertainty, but it might be a good thing to have. Journal of Business Strategy. 25 (1), 57-59

10. Ojha Divesh, (2008). Impact of Strategic Agility on Competitive Capabilities and Financial Performance. Dissertation, Graduate School of Clemson University.

11. Swafford P. M, Ghosh S, Murthy N (2006), The antecedents of supply chain agility of a firm: Scale development and model testing, Journal of Operations Management, Vol. 24, pp. 170-188

12. Sull, D. (2009), How to Thrive in Turbulent Markets, Harvard Business Review, Vol. 87 Issue 2, p78-88.

13. Turban E, Leidner D, Mclean E, Wetherbe J (eds.) (2008), Information Technology Management: Transforming Organisations in the digital Economy. John Wiley \& Sons Ltd.

14. Wiggins, R.R., Ruefli, T. W. (2005), Schumpter's Ghost: Is hypercompetition making the best of times shorter? Strategic management Journal, Vol. 26, No. 10,pp. 887-911 